\title{
Factors of sustainable development of energy technologies in the formation of digital economy
}

\author{
Elena Avdeeva ${ }^{1}$, Tatiana Davydova ${ }^{1}$, Oksana Belyantseva ${ }^{1}$, and Tatyana Makeeva ${ }^{1, *}$ \\ ${ }^{1}$ Voronezh State Technical University, 14, Moscovskiy prospect, 394026, Voronezh, Russia
}

\begin{abstract}
Efficiency in the use of energy resources is a priority for the "smart cities" trajectory of sustainable development. This is an essential condition for improving the economic, social and environmental well-being of citizens in general. The importance of life systems orientation to the consumer as an effective user is emphasized. The factors of sustainable development of technologies were identified: updating and modernization of fixed assets in the fuel and energy complex and other sectors of the economy, social and industrial infrastructure on a new technological and energy-efficient basis; provision of forecasting, full accounting and regulation of energy resources consumption, as well as reduction of their losses. The directions of increasing the energy systems efficiency in various sectors are generalized. The necessity of developing human resources through digital skills training was emphasized.
\end{abstract}

\section{Introduction}

World cities account for about $75 \%$ of global energy consumption and greenhouse gas emissions [1]. The cost of energy consumed in public buildings in the fields of education, healthcare, administrative management, makes up a significant part of the total expenditures of the public sector [2], and buildings make up 35\% of the global final energy demand [3].

Global mitigation of climate change, environmental sustainability in general $[1,4,5]$; energy efficiency $[6,7]$, addressing the safety of urban residents [8]; attracting residents to optimize ways to solve problems in the application to urban living $[8,9,10,11]$ require the implementation of an intellectual policy for the creation of "smart homes" and "smart cities". "Smart systems" involve global digitalization of the life support system as a whole. The central role is given to Smart Energy Systems [12]. Human society is increasingly affecting the planet and its ecological system. Existing problems indicate that production and consumption patterns are not sustainable [13]. The noted positions highlight the

\footnotetext{
*Corresponding author: belyaeva-sv@mail.ru
} 
relevance of the study of the sustainability factors of appropriate technologies. The role of information technology and the digital economy is considered from the perspective of building the potential of promoting the creation of a "smart city" in order to improve the quality and standard of living of citizens.

\section{Materials and Methods}

Today, digital energy security is based on the following key concepts: dynamic sustainability and cybersecurity. Dynamic stability is understood as the ability of the system to restore an initial state or a state almost close to the initial state after a big disturbance, and cybersecurity as the main set of precautions and monitoring that all ICT users should take. This includes informing, safely configuring equipment and networks, updating software, refusing to provide employees and users with unnecessary system privileges or data access rights, and training [14].

Confidentiality and ownership of data is also a serious problem for consumers, especially since more detailed data is collected from a growing number of connected devices. For example, household energy use data collected using smart meters can be used to determine when someone is at home taking a shower or cooking.

Energy technologies in a smart city can be evaluated from the perspective of energy conservation and the implementation of technological solutions. In the first case, we propose to focus on approaches to energy conservation, taking into account the construction and operation of smart buildings. Energy saving is based on appropriate technology. For the construction of buildings, this is, first of all, heating systems, as a rule, taking into account the environmental component. Priority is given to the choice of the spatial orientation of the building, zoning, construction and finishing materials. Technologies of this kind do not take into account the human factor, which reflects consumer behavior strategies. Thus, these technologies can be considered as independent; the result of their application is predicted with a high degree of accuracy. With regard to energy technologies involving direct consumer participation, their significant impact is recognized [15]. There are polar opinions regarding the role of consumers. So, on the one hand, their behavior is assessed as an obstacle to effective interaction, on the other hand, as a resource that must be used [16]. Further, C. Pelau and C. Acatrinei, having examined the effects of digitalization on household energy consumption, conclude that an increase in the number of consumers determines lower energy consumption in the digital economy [17].

From the perspective of the implementation of technological solutions to the consumer, it is advisable to consider both the goal and the resource, since any technological solution is developed taking into account consumer preferences, and is focused on it. It is in this aspect that the connection between the welfare of the population and the transformations related to the use of modern energy technologies is considered. In particular, the priority of state policy is emphasized, including the provision of energy efficiency in the digital economy by the example of creating a "moderately well-off society" [18]. Smart city management is seen as a critical requirement for improving the economic, social and environmental wellbeing of citizens [19]. In addition, the customer focus of all systems providing life support in cities is increasing, and consumer reaction is becoming a key component of the concept, which assumes the sustainable use of energy. Human and human potential gains a new understanding in the light of the digitalization of the economy [20].

Note that in the Russian Federation an irrational environmental management scheme is used. On the one hand, irreparable damage is caused to the environment, the climate of the entire planet, and on the other, the necessary residues of raw materials are burned. According to the State Statistics Committee of the Russian Federation, the volumes of energy production and consumption are significant - 1012 billion $\mathrm{kWh}$. for 11 months of 
2019 and have a tendency to increase by $1.2 \%$ in general and by $3.5 \%$ increased energy produced by nuclear power plants. The release of steam and hot water fell in 2019 by $2.2 \%$, but the total volume is also impressive - 1,093 million Gcal (Table 1).

Table 1. Production of the most important types of products in the Russian Federation.

\begin{tabular}{|l|c|c|}
\hline \multicolumn{1}{|c|}{$\begin{array}{c}\text { Production output in the Russian } \\
\text { Federation }\end{array}$} & $\begin{array}{c}\text { January-November } \\
\mathbf{2 0 1 9} \text { year }\end{array}$ & $\begin{array}{c}\text { January-November } \\
\mathbf{2 0 1 9} \text { year } \\
\mathbf{v} \% \text { k } \\
\text { January-November } \\
\mathbf{2 0 1 8} \text { year }\end{array}$ \\
\hline Electricity. billion kW $\mathrm{h}$ & 1012 & 101.2 \\
\hline $\begin{array}{l}\text { including those produced by power } \\
\text { plants: } \\
\text { atomic }\end{array}$ & 191 & 103.5 \\
\hline thermal & 640 & 100.5 \\
\hline hydropower plants & 179 & 100.9 \\
\hline Steam and hot water. million Gcal & 1093 & 97.8 \\
\hline $\begin{array}{l}\text { including released: } \\
\text { power plants }\end{array}$ & 510 & 97.6 \\
\hline boiler rooms & 498 & 97.7 \\
\hline industrial recycling plants & 82.2 & 99.7 \\
\hline
\end{tabular}

Scientists believe that the only source of renewable energy is suitable for large-scale energy - geothermal energy. At the same time, this is not the energy that is still used in our regions and the country. The priority here should be the potential of constantly heated underground rocks - petrogeothermal energy (PGE), which is many times higher than the energy potential of thermal waters and is also available anywhere in the world. For the first time, energy conversion installations for low-temperature thermal water appeared abroad. These installations in the Russian Federation are currently available in experimental design.

Politicians, business executives, and other stakeholders are increasingly confronted with new and complex problems, as well as incomplete or imperfect information [21]. We single out a number of the most significant factors holding back the sustainable development of energy systems.

Firstly, the extremely dynamic nature of energy systems, due to their high capital intensity and long regulatory life (for the main equipment of thermal power plants and nuclear power plants - 30 years, for equipment of hydroelectric power stations - 40 years, for hydraulic structures - 100 years).

Secondly, the susceptibility of energy systems to moral, social, environmental deterioration. The obsolescence comes as a result of the use of advanced technologies in industries producing fixed assets and changes in the economic conditions of production, as well as the introduction of new highly economical equipment. By social depreciation we understand the increase in accident rate and the danger of operating the facility. Environmental deterioration occurs due to non-compliance with environmental standards.

Thirdly, the lack of digital skills and internal barriers related to the company's culture and thinking are the biggest obstacles to digital progress in the energy sector. About $71 \%$ of organizations in the industry need staff with joint experience working with domains and digital technologies, and $18 \%$ claim that they do not have a single employee with such a combined set of skills [22].

The industrial sector has used process control and automation for decades, especially in heavy industry, to maximize quality and productivity with minimal energy use. Intelligent transport systems use digital technology on all modes of transport to increase safety, reliability and efficiency. 
The use of digital solutions for freight and logistics can reduce energy consumption by road transport by $20-25 \%$. Examples of such solutions are GPS combined with real-time traffic information for route optimization, on-board monitoring and feedback, which improves the efficiency of environmentally friendly driving, the ability to connect vehicles that can safely reduce the gaps between truck platoons to increase fuel efficiency, and data exchange between companies throughout the supply chain to ship more goods in less travel.

\section{Results}

In combination with environmental intelligence technologies, smart metering will allow smart homes to dynamically adjust energy consumption, for example, turn off the heating when no one is in the room or automatically adjust the lighting depending on the actions taking place in the room. For electricity providers, smart energy systems provide energy where it is needed, when needed, by accurately matching supply and demand, thereby reducing the need for wasteful excess power, while increasing the integration of renewable energy sources such as wind and solar energy.

The global goal of modern society is sustainable development. Smart systems in the digital economy through the efficient use of energy technology determine its feasibility. At the same time, groups of factors are taken into account that relate to the basic spheres of human life and have a direct impact on the level of his well-being (Fig. 1).

\begin{tabular}{|c|c|c|c|c|}
\hline & \multicolumn{3}{|c|}{ Smart systems } & \\
\hline & \multicolumn{3}{|c|}{ Energy technology } & \\
\hline & \multicolumn{3}{|c|}{ Digital infrastructure } & \\
\hline $\begin{array}{l}\text { Social } \\
\text { sphere }\end{array}$ & $\begin{array}{l}\text { Economic } \\
\text { sphere }\end{array}$ & $\begin{array}{c}\text { Environmental } \\
\text { sphere }\end{array}$ & $\begin{array}{c}\text { Technology } \\
\text { sphere }\end{array}$ & $\begin{array}{c}\text { Innovation } \\
\text { sphere }\end{array}$ \\
\hline & \multicolumn{3}{|c|}{ Welfare } & \\
\hline & \multicolumn{3}{|c|}{ Sustainable development } & \\
\hline
\end{tabular}

Fig. 1. Hierarchical interconnection of elements of the sustainable development system.

The analysis showed that sustainable development is possible with the natural interest of the stakeholders in mutually beneficial cooperation. This is possible when both the manufacturer and the consumer of the results of the energy technologies development in the "smart city" system clearly understand each other's functions and in some cases perform common functions [23].

Thus, the pace of sustainable development will depend on the combined impact of changes in consumer behavior, political intervention, technological progress and vehicle technology.

It is important to draw up plans and forecasts in several versions of the required amount of each energy resource, depending on the known need and expected one. This will make it possible to calculate the resource consumption for all consumers of the system [24]. The task of the best distribution of a certain energy resource between resource units (business processes or business units responsible for their implementation) and functional units (various consumers) under various restrictions on the size of the attracted resource can be solved using the functional process model. When constructing the matrix, we accept that the rows of the matrix denote business processes, and the columns indicate potential consumers. The numerical value of each cell denotes the amount of the analyzed resource consumed by this element of the system. Summing the values of the resource by the 
columns of the matrix allows us to estimate its consumption per individual consumer, and by the lines shows how much resource will be required to develop a separate resource unit.

Given the known resource needs of individual elements of the system $\left(\mathrm{X}_{\mathrm{pij}}\right)$ and restrictions $\left(a_{p}, b_{p}\right)$ on the use by a separate resource unit of the corresponding resource (electricity, gas, water):

$\mathrm{a}_{\mathrm{pij}}$ - the minimum amount of a resource of some type that can be used by a consumer of a resource unit;

$\mathrm{b}_{\mathrm{pij}}$ - the maximum amount of a resource of some type that can be used by a consumer of a resource unit;

$$
\begin{gathered}
a_{p i} \leq \sum_{i=1}^{M} \mathrm{X}_{\mathrm{pij}} \leq \mathrm{b}_{\mathrm{pi}} \\
\sum_{i=1}^{N} \mathrm{a}_{\mathrm{pi}} \leq C_{p} \leq \sum_{i=1}^{N} b_{p i}
\end{gathered}
$$

It is required to determine the needs of other matrix cells and the total amount of resource consumed $\left(\mathrm{C}_{\mathrm{p}}\right)$.

If $a_{p}=b_{p}$, then

$$
\sum_{i=1}^{N} \sum_{j=1}^{M} a_{p i j}=C_{p}=\sum_{i=1}^{N} \sum_{j=1}^{M} b_{p i j}
$$

There is a unique solution to the problem and the distribution of resources is determined by the formula:

$$
x_{p i j}=C_{p} k_{p i} r_{p i j}
$$

If the amount of consumed resource is not set rigidly and can vary between the upper and lower boundaries, the resource requirements of individual consumers can vary within their limitations, often depending on external circumstances of a qualitative nature. In this situation, the procedure for determining the best option for the distribution of the resource among consumers is iterative in nature, where the formula is used to control calculations:

$$
C p=\sum_{i=1}^{N} \sum_{j=1}^{M} k_{p i} r_{p i j} x_{p i j}
$$

The determination of the unknown elements of the matrix can be carried out on the basis of the minimum necessary requirements (lower boundary). In this case, if the amount of the resource consumed by individual given elements $\left(\mathrm{X}_{\mathrm{pij}}\right)$ is known and equal to $\mathrm{d}$, where

$$
d_{p}=\sum_{i=1}^{N} \sum_{j=1}^{M} x_{p i j}
$$

The remaining unused resource (up to the lower boundary) can be reserved or distributed between the remaining unknown elements of the matrix $\left(\mathrm{X}_{\mathrm{pij}}\right)$ in accordance with the modified formula (4): 


$$
x_{p i j}=\left(a_{p}-d_{p}\right) k_{p i} r_{p i j}
$$

Natural monopolies serve different regions, therefore, when modeling the distribution of energy resources, it is advisable to take into account the territorial factor. In this case, it is possible to supplement the considered matrix with another dimension, by which it is possible to postpone the parameters characterizing the costs of resources arising in connection with the peculiarities of the territorial location. An axis with regions is displayed in the 3D matrix. In this case, the total amount of rows or columns will reflect the consumption of the analyzed type of resource not only for the type of producer and consumer of energy resources, but also for a certain territory.

\section{Discussions}

The feasibility and prospects of the "smart systems" introduction can be said by the results of the foreign economies development. Today, more than $50 \%$ of households in the US and Europe are "smart". A typical American household now uses more air conditioning, home appliances and consumer electronics than ever before. However, the average annual energy consumption per house has decreased. The reasons for this decline are to improve the thermal insulation of buildings and materials, increase the efficiency of heating and cooling equipment and devices, migrate the population to regions with lower heat consumption and, consequently, lower overall energy consumption.

The number of houses is growing, energy consumption is decreasing - energy is being saved. Moreover, the average household living in a separate single-family house consumes almost three times more energy than a household living in an apartment building with five or more apartments. The needs for the implementation of "smart systems" in various spheres of life become, for the most part, basic, and are not considered as necessary and additional [23]. Accordingly, the view on the significant factors of welfare gains and sustainable development can be adjusted (table.2).

Table 2. Directions for improving the efficiency of energy systems in various sectors and the quality of life as a result of digitalization.

\begin{tabular}{|c|c|c|}
\hline In the consumer sector & In the industrial sector & $\begin{array}{l}\text { In the field of energy } \\
\text { systems }\end{array}$ \\
\hline $\begin{array}{l}\text { - Increased responsiveness } \\
\text { of energy services - light } \\
\text { sensors, dimmers, } \\
\text { temperature settings to } \\
\text { reduce or save energy } \\
\text { demand } \\
\text { forecasting user behavior } \\
\text { - automatic } \\
\text { programming of the } \\
\text { heating and cooling } \\
\text { service, reducing energy } \\
\text { demand at a specific } \\
\text { time } \\
\text { intelligent thermostats } \\
\text { and intelligent lighting } \\
\text { (LED and fluorescent } \\
\text { sources). }\end{array}$ & 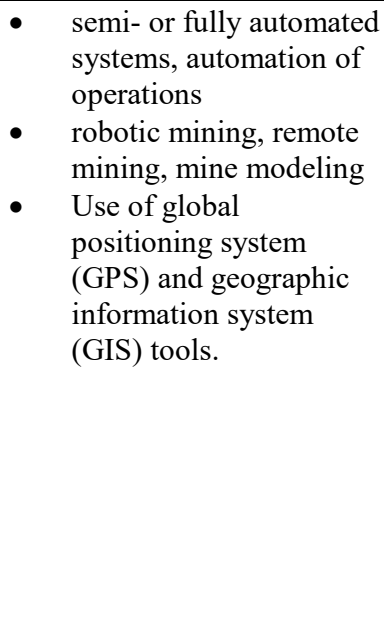 & $\begin{array}{l}\text {-improved planning } \\
\text { - increasing the efficiency of } \\
\text { combustion at power } \\
\text { plants and reducing } \\
\text { losses in networks } \\
\text { - best design throughout the } \\
\text { power system } \\
\text {-reduction of losses in the } \\
\text { delivery of electricity to } \\
\text { consumers, for example, } \\
\text { due to remote } \\
\text { monitoring, allowing to } \\
\text { approach its optimal } \\
\text { conditions for the use of } \\
\text { equipment. }\end{array}$ \\
\hline
\end{tabular}

Estimates of various experts determine the energy saving potential in Russia at $35-45 \%$ of today's energy consumption, which is about 400 million tons of standard fuel. In 
Moscow, the energy saving potential is 11 million tons of equivalent fuel per year. And today, society's investments should not be directed to the development of new deposits, but to energy saving.

\section{Conclusion}

From the point of view of the implementation of technological solutions in the digital consumer economy, it is advisable to consider both as a goal and as a resource. The management of smart cities is assessed as an essential requirement for improving the economic, social and environmental well-being of citizens in general. The importance of orienting life systems to consumers is growing, and their reaction is seen as the main component of the "smart city" concept, which involves, first of all, the development of sustainable energy technologies with efficient use of energy. Technology development factors are considered taking into account their importance from the position of the consumer and, first of all, his well-being.

The effects of designing a model for realizing energy saving potential, using an integrated approach, are determined by updating and modernizing fixed assets in the fuel and energy sector and other sectors of the economy, social and industrial infrastructure on a new technological and energy-efficient basis, and reducing the burden of paying for energy carriers to the federal, regional and municipal budgets, ensuring full accounting and regulation of the energy resources consumption, as well as reducing the level of their losses. The development of human resources and energy management in the areas of energy production and energy consumption of enterprises contributes to the strengthening of the information and statistical base for managing and monitoring processes to improve energy efficiency of enterprises.

\section{References}

1. S.J. Wang, P. Moriarty, Innovative Solutions for Energy Transitions 158, 3271-3276 (2019)

2. M. Zekie-Susac, M. Knezevic, R. Scitovski, Proc. 14th Int. Conf. on Soft Computing Models in Industrial and Environmental Applications (SOCO 2019) 950, 101-110 (2020)

3. J.R. Vazquez-Canteli, S. Ulyanin, J. Kampf, Z. Nagy, Sustainable Cities AND Society 45, 243-257 (2019)

4. K.L. Ipsen, R.K. Zimmermann, P.S. Nielsen, M. Birkved, International Journal of Life Cycle Assessment 24(7), 1239-1253 (2019)

5. R. Berquier, D. Gibassier, Sustainability Accounting Management and Policy Journal 10(4), 710-744 (2019)

6. A. Mutule, J. Teremranova, Latvian Journal of Physics and Technical Sciences 55(6), 52-62 (2018)

7. R. Peto, Interdisciplinary Description of Complex Systems 17(1), 13-19 (2019)

8. A. Nilsson, M. Wester, D. Lazarevic, N. Brandt, Energy and Buildings 179 15-25 (2018)

9. A. Bhati, M. Hansen, C.M. Chan, Energy Policy 104, 230-239 (2017)

10. I. Vassileva, F. Wallin, E. Dahlquist, Energy 46(1), 94-100 (2012)

11. M.V. Moreno, M.A. Zamora, A.F. Skarmeta, Transactions on Emerging Telecommunications Technologies 25(1), 41-55 (2014) 
12. A. Blumberga, R. Freimanis, I. Muizniece, K. Spalvins, D. Blumberga, Energy 186, UNSP 115741 (2019)

13. M. Pouri, L. Hilty, Sustainability 10(12), 4453 (2018)

14. E. Zubeeva, M. Mirgorodskaya, Yu. Geraskin, A. Chugunov, O. Belyantseva, MATEC Web of Conferences, conference proceedings 170, 01097 (2018)

15. Y. Bondarenko, T. Azarnova, I. Kashirina, T.A. Averina, Advances in Intelligent Systems and Computing 983, 69-78 (2019)

16. R. Bull, M. Azennoud, Proceedings of the Institution of Civil Engineers-Energy 169(3), 93-101 (2016)

17. C. Pelau, C. Acatrinei, Energies 12(8), 1428 (2019)

18. M. Sanwal, X. Zheng, Climate Policy 18(1), 36-41 (2018)

19. E. Avdeeva, O. Belyantseva, E. Smorodina, Proc. Int. Conf. on MATEC Web of Conferences Siberian Transport Forum - TransSiberia 2018, 08004 (2018)

20. T. Davydova, E. Avdeeva, L. Kochetova, T. Makeeva, Proc. Int. Conf. on Competitive, Sustainable and Safe Development of the Regional Economy (CSSDRE 2019) 83, 204207 (2019)

21. S.A. Barkalov, O.S. Perevalova, T.A. Averina, Proceedings of 2018 11th International Conference "Management of Large-Scale System Development", 8551863 (2018)

22. K. Kulakov, S. Belyaeva, O. Belyantseva, A. Gamisoniya, MATEC Web of Conferences 170, 01118 (2018)

23. E. Avdeeva, T. Davydova, N. Skripnikova, L. Kochetova, E3S Web of Conferences 110, 02139 (2019)

24. Yu.V. Bondarenko, T.A. Sviridova, T.A. Averina, IOP Conference Series: Materials Science and Engineering International Workshop "Advanced Technologies in Material Science, Mechanical and Automation Engineering - MIP: Engineering - 2019", 42045 (2019) 